\title{
Toward a Jurisprudence of the Civil Rights Acts
}

Robin West

Georgetown University Law Center, west@law.georgetown.edu

This paper can be downloaded free of charge from:

https://scholarship.law.georgetown.edu/facpub/1299

http://ssrn.com/abstract=2363036

Robin West, Toward a Jurisprudence of the Civil Rights Acts, in A NATION OF WIDENING OPPORTUNITIES? THE CIVIL RIGHTS ACT AT FIFTY, (Samuel Bagenstos and Ellen Katz, eds., University of Michigan Press forthcoming 2014)

This open-access article is brought to you by the Georgetown Law Library. Posted with permission of the author. Follow this and additional works at: https://scholarship.law.georgetown.edu/facpub

Part of the Civil Rights and Discrimination Commons, Construction Law Commons, Jurisprudence Commons, and the Legal Writing and Research Commons 


\section{Toward a Jurisprudence of the Civil Rights Acts}

Robin L. West

What is the nature of the "rights," jurisprudentially, that the 1964 Civil Rights Act ${ }^{1}$ legally prescribed? And, more generally, what is a "civil right"? Today, lawyers tend to think of civil rights and particularly those that originated in the 1964 Act, as antidiscrimination rights: our "civil rights," on this understanding, are our rights not to be discriminated against, by employers, schools, landlords, property vendors, hoteliers, restaurant owners, and providers of public transportation, no less than by states and state actors, on the basis of race, gender, ethnicity, age, sexuality or disability. Contemporary civil rights scholarship overwhelmingly reflects the same conception: our civil rights are quasiconstitutional rights to be free of discrimination in the private as well as public world. ${ }^{2}$ But this conventional lawyerly understanding—basically, that "civil rights" are "antidiscrimination rights" - is clearly inadequate, certainly with respect to civil rights generally but also, and more tellingly, even with respect to the rights created and then protected by the '64 Act itself.

First, on the general point: some of the "civil rights" sought or held across our history have not been antidiscrimination rights of any sort at all—labor rights, welfare rights, free speech rights, and the constitutional rights of criminal defendants have all, at various times, been championed as "civil rights," and these rights are neither logically nor jurisprudentially tied to any conception of antidiscrimination. ${ }^{3}$ But furthermore, even the "civil rights" which are defined and then protected against discrimination by the 1964 Civil Rights Act, as well as by various Civil Rights Acts both before and subsequent to it, are not, in circular fashion,

\footnotetext{
${ }^{1}$ Civil Rights Act of 1964, 42 U.S.C. §§ 2000e to 2000e-17 (2013).

${ }^{2}$ The identification of civil rights with the antidiscrimination norm is ubiquitous in contemporary scholarship on the Civil Rights Act. See, e.g., Bruce Ackerman, The Living Constitution, 120 HARV. L. REV. 1737, 1779-80 (2007); William N. Eskridge, Jr. \& John Ferejohn, Super-Statutes, 50 DUKE L.J. 1215, 1237-38 (2001); Rebecca E. Zietlow, To Secure These Rights: Congress, Courts and the 1964 Civil Rights Act, 57 RuTGERS L. REV. 945, 946 (2005). For an historical account of how this identification became entrenched in twentieth century legal thought, and an attempt to reclaim earlier meanings, see RisA L. Goluboff, The Lost PROMISE OF Civil Rights (2010) [hereinafter GolubOFF, LOST PROMISE]; Risa L. Goluboff, The Thirteenth Amendment and the Lost Origins of Civil Rights, 50 DuKE L.J. 1609 (2001) [hereinafter Goluboff, Thirteenth Amendment].

${ }^{3}$ Labor rights in particular were identified and then fought for as "civil rights" through the first half of the twentieth century, not just in common parlance, but also by the Justice Department's Civil Rights Section lawyers charged with the duty of enforcing them. See Goluboff, Thirteenth Amendment, supra note 2, at 1616-18; see generally William E. Forbath, Caste, Class, and Equal Citizenship, 98 Mich. L. REv. 1, 4-6 (1999) [hereinafter Forbath, Caste]; William E. Forbath, Civil Rights and Economic Citizenship: Notes on the Past and Future of the Civil Rights and Labor Movements, 2 U. PA. J. LAB. \& EMP. L. 697 (2000) [hereinafter Forbath, Past and Future].
} 
simply our rights not to be discriminated against on the basis of impermissible characteristics. Rather, the "civil rights" of which we cannot be discriminatorily deprived, whether originating in the '64 Act or elsewhere, are, after all, rights to something: to vote, ${ }^{4}$ to physical security, ${ }^{5}$ to enter contracts, ${ }^{6}$ to own, buy, or sell property, ${ }^{7}$ to legal recourse in the aftermath of a wrong committed against us, ${ }^{8}$ to write a will, ${ }^{9}$ to be considered for or to hold down a job and to be paid fairly for our labor, ${ }^{10}$ to the use of a restaurant or a hotel or a city bus, ${ }^{11}$ to a public education, ${ }^{12}$ to marry whom we love. ${ }^{13}$ And, these are just some of the public goods that have been recognized at various times as "civil rights," of which we cannot be deprived by discriminatory action.

Even if just that much is correct, then the "civil right" protected by all of our Civil Rights Acts, including the '64 one, is considerably more complex, jurisprudentially, than the conventionally legalistic and formulaic equation of "civil rights" with "antidiscrimination rights" suggests. Minimally, the "civil right" recognized or protected by the various Civil Rights Acts is almost invariably a multilayered right, or a "right to a right": it is a right to not

4. See Voting Rights Act of 1965, Pub. L. 89-110, 79 Stat. 437 (codified as amended in scattered sections of 42 U.S.C.) (2013) ("All citizens of the United States who are otherwise qualified by law to vote ... shall be entitled and allowed to vote at all such elections, without distinction of race, color, or previous condition of servitude.”); see also the Civil Rights Act of 1957, Pub. L. No. 85-315, 71 Stat. 634 (1957) (current version at Voting Rights Act of 1965); Civil Rights Act of 1960, Pub. L. No. 86-449, 74 Stat. 86 (1960) (current version at Voting Rights Act of 1965).

${ }^{5}$ Civil Rights Act of 1866, ch. 31, § 1, 14 Stat. 27 (1866) (emphasis added):

And such citizens, of every race and color, without regard to any previous condition of slavery or involuntary servitude, except as a punishment for crime whereof the party shall have been duly convicted, shall have the same right, in every State and Territory in the United States, to make and enforce contracts, to sue, be parties, and give evidence, to inherit, purchase, lease, sell, hold, and convey real and personal property, and to full and equal benefit of all laws and proceedings for the security of person [execution, imprisonment] and property, as is enjoyed by white citizens, and shall be subject to like punishment, pains, and penalties, and to none other, any law, statute, ordinance, regulation, or custom, to the contrary notwithstanding.

See also Ku Klux Klan Act of 1871, 42 U.S.C. §§ 1983, 1985, 1986 (2013), also called the Civil Rights Act of 1871 or the Force Act of 1871, which was intended to secure for African Americans the protection of the criminal law against private violence.

${ }_{7}^{6}$ Civil Rights Act of 1866, ch. 31, § 1, 14 Stat. 27 (1866).

${ }^{7}$ Id.

${ }^{8}$ Id.

${ }^{9} \mathrm{Id}$.

${ }^{10} 42$ U.S.C. § 2000e (2013).

${ }^{11} 42$ U.S.C. § 2000a (2013). See also Civil Rights Act of 1875, ch. 114, §§ 3-5, 18 Stat. 336, 337 (1875) (held unconstitutional in The Civil Rights Cases, 109 U.S. 3 (1883)).

${ }^{12}$ Title IX of the Education Amendments of 1972, 20 U.S.C. §§ 1681-88 (2013).

${ }^{13}$ See United States v. Windsor, 133 S.Ct. 2675 (2013); Loving v. Virginia, 388 U.S. 1 (1967); Goodridge v. Dep’t of Pub. Health, 798 N.E.2d 941 (Mass. 2003). 
be discriminatorily deprived of some underlying right. Only the first right in that phrase "a right to a right" is the antidiscrimination right. The second "right," though, is the underlying civil right of which we cannot be discriminatorily deprived, and it is both itself complex and highly variable: it might be a common law right, such as a right to enter contracts or sell property, or a statutory right, such as a right to vote, or simply a right to a social or public good, such as employment or educational opportunities, or the protection of a trustworthy police force against private violence. And, while we have generated a library of writing, and jurisprudence, and judicial opinions, on the nature of the first "right" in that phrase-the right not to be deprived of various rights, on the basis of race, sex, and so forth-we have devoted much less to the second: the nature of the underlying right of which we cannot be deprived. So, what is the jurisprudential nature of that right? What is a "civil right," jurisprudentially, both with respect to the rights protected against discrimination by the Civil Rights Act of 1964, and more broadly? Again, and more generally, what is a "civil right"?

Oddly, I believe, and in spite of their unquestioned importance in our contemporary public life, we are woefully short on a jurisprudential understanding of civil rights, both with respect to the Civil Rights Act of 1964, whose fiftieth anniversary we celebrate this year, and more broadly. Although we've recently seen an explosion of scholarship on the history, or histories, of both the civil rights movement of the 1950s through 1970s, and of the Civil Rights Acts they produced, ${ }^{14}$ there has not been, either during or following our various "legislative moments" ushering in civil rights laws, a body of scholarly work engaged in reflective debate over the jurisprudential nature of the civil rights they sought to win and then to protect. We simply do not have a scholarly jurisprudential canon that seeks to encompass not only the nature of the antidiscrimination norm that our various civil rights acts codify, but also the nature of the substantive underlying rights that all those rights against discrimination protect. Legal scholars have, for better or worse, focused on judge-made law, and particularly judge made constitutional law, when engaging in the work of discerning the overarching principles of rights-based jurisprudence. Nowhere is this more clear than in the areas of law and life touched by the Civil Rights Acts themselves. I will return to this problem below. Here, I just want to note that for whatever reason, our scholarship on civil rights has shortchanged the complexities of both the Civil Rights Acts, and of civil rights movements and their product - civil rights - more broadly construed. We have focused our jurisprudential scholarship almost entirely on the rights to nondiscrimination our Civil Rights Acts created. But we have neglected the need to understand the nature of the underlying rights of access to the social goods, systems of law, or institutions-contractual freedom and

\footnotetext{
${ }^{14}$ See, e.g., GolubOFF, LOST Promise, supra note 2; Kenneth Mack, RePresenting THE RACE: THE CREATION OF THE CiVIL RightS LAWYER (2012); Bruce Ackerman, The Living Constitution, 120 HARV. L. REV. 1737 (2007); Risa L. Goluboff, Lawyers, Law and the New Civil Rights History, 126 Harvard L. Rev. 2312 (2013); Goluboff, Thirteenth Amendment, supra note 2; Kenneth Mack, Rethinking Civil Rights Lawyering and Politics in the Era Before Brown, 115 Yale L.J. 256 (2005) [hereinafter Mack, Rethinking Civil Rights]; G. Edward White, The Origins of Civil Rights in America, 64 CASE W. RES. L. REV. (forthcoming 2014) (available at papers.ssrn.com/sol3/papers.cfm?abstract_id=2251425); Rebecca E. Zietlow, To Secure These Rights: Congress, Courts, and the 1964 Civil Rights Act, 57 RutGERS L. REV. 945 (2005).
} 
powers, property ownership, education, employment opportunities, public accommodation, family life, and so on - that those nondiscrimination rights were designed to protect.

This is a neglect that matters, beyond the obvious problem that the neglect itself fosters confusion, with disputants and debaters often talking at cross-purposes. ${ }^{15}$ There are at least two deeper worries. First, the lack of a jurisprudence of the Civil Rights Acts that centers the underlying civil rights, and not just the antidiscrimination norm, likely reflects as well as contributes to a lack of appreciation of the civil society, and of the law that facilitates it, that "civil rights," historically and today, both depend upon and produce. We have a welldeveloped jurisprudential scholarship on the nature of rights, including natural rights, human rights, legal rights, and constitutional rights. ${ }^{16}$ And, we have a well developed body of scholarship concerning civil society - but it is a peculiarly legally denuded civil society that, thus far, we have studied: it is the "civil society" of voluntary bowling leagues and private associations, often definitionally set apart from or in opposition to the legal society of the

${ }^{15}$ For example, Jack Balkin's review of Ackerman's Holmes lecture on the history and meaning of the "civil rights revolution" of the 1960s, which included, according to Balkin, the rights of criminal defendants to Miranda warnings, habeas corpus, legal representation, and so forth. Jack M. Balkin, A Review of Bruce Ackerman's Holmes Lectures, "The Living Constitution”, Part One, BALKInIZATIOn (May 29, 2007, 6:50 AM), http://balkin.blogspot.com/2007/05/review-of-bruce-ackermans-holmes.html; Jack M. Balkin, A Review of Bruce Ackerman's Holmes Lectures, “The Living Constitution,” Part Two, BALKINIZATION (May 30, 2007, 6:51 AM), http://balkin.blogspot.com/2007/05/reviewof-bruce-ackermans-holmes_30.html; Jack M. Balkin, A Review of Bruce Ackerman's Holmes Lectures, “The Living Constitution”, Part III, BALKINIZATION (May 31, 2007, 6:50 AM), http://balkin.blogspot.com/2007/05/review-of-bruce-ackermans-holmes_31.html; Jack M. Balkin, A Review of Bruce Ackerman's Holmes Lectures, “The Living Constitution,” Part Four, BALKinizATiOn (June 1, 2007, 6:50 AM), http://balkin.blogspot.com/2007/06/reviewof-bruce-ackermans-holmes.html. But without some sort of jurisprudential understanding of the nature of a civil right, such that these rights of criminal defendants are core examples of such rights, it is hard not to view this critique as simply arbitrary.

${ }^{16}$ On the nature of rights, see, e.g., RONALD DWORKIN, LAW's EMPIRE (1986); RONALD DWORKIn, A MATTER OF PRINCIPLE (1985); RONALD DWORKIN, TAKING RightS SERIOUSLY (1978); H.L.A. HART, ESSAYS ON BENTHAM: JURISPRUDENCE AND POLITICAL THEORY (1982); WESLEy NEWCOMB HOHFELD, FundAMENTAl LEGAl CONCEPTIONS: AS APPLIED IN JUdiCiAL REASONING (Walter Wheeler Cook, ed., Yale Univ. Press 1964). See generally, THEORIES OF RigHTS (Jeremy Waldron, ed., 1984). On natural rights or human rights, see, e.g., JOHN FinNis, NATURAL LAW \& NATURAL Rights (2d ed. 2011); MARTHA C. NusSBAum, Women AND Human DeVElopment: The CAPABILITIES ApPROACH (2001) [hereinafter Nussbaum, Women and Human Development]. On Constitutional Rights, see Laurence H. Tribe, AMERICAN CONSTITUTIONAL LAW (3rd sub ed. 1999). For critical treatments of our constitutional rights tradition, see MARY ANN GLENDON, RigHTS TALK: THE IMPOVERISHMENT OF POLITICAL DisCOURSE (Free Press reprt. ed. 1993); Morton J. Horwitz, Rights, 23 HARV. C.R.-C.L. L. REV. 393 (1988); Mark Tushnet, An Essay on Rights, 62 TEX. L. REV. 1363 (1984). 
Courthouse and City Hall. ${ }^{17}$ We don't have much, if any, scholarship seeking to understand the civil society structured, and facilitated, by positive law, and we have virtually none centering the nature of our rights to participate in it.

But second, the lack of jurisprudential study of the underlying civil rights protected by our various Civil Rights Acts throughout our history has quite possibly skewed, and perhaps truncated, our inherited civil rights traditions, as well as possibilities for their creative regeneration. Civil rights, as well as the civic and participatory life they facilitate, can be threatened not only by discriminatory private practices of the sort prohibited by the Civil Rights Acts, but by much else as well. Our natural rights to participate in family life can be threatened not only by discriminatory state marriage law that grants rights to form families or marriages to some but not others, but also by private or intimate violence within those marriages that goes unaddressed by states, by a punitive criminal justice system that over-incarcerates marriageable men for trivial or victimless offenses, and by a lack of community support for our caregiving obligations. Our civil rights to a healthy and physically secure life can be threatened not only by sexually discriminatory medical treatment or racially discriminatory policing and profiling, but also by a lack of affordable health care, a lack of trustworthy police protection against private or neighborhood violence, and an unhealthy and polluted planet. Our rights to decent employment opportunities can be denied us not only by intentional discrimination or neutral rules with discriminatory impacts, but also by a lack of skills and skills training, jobs outsourcing, plant relocations, capital strikes and high unemployment. Our rights to education are frustrated by a lack of preschool readiness and lack of community support for parents of newborns, infants and toddlers, as much as by racially discriminatory admissions or school districting policies. To secure these rights, then, to family life, education, employment, and physical security (assuming for the moment we have such rights), we do indeed need to enforce laws against discrimination. But we need to do much else as well. The scholarly focus of the last fifty years on the nature of discrimination and its unlawfulness, rather than on the full array of obstacles that stand as barriers to the enjoyment of civil rights, and without insisting on the point that discrimination is but one such obstacle among others, has shrunk our understanding and appreciation of our own civil rights tradition, as well as its regenerative potential.

This essay seeks to begin such a conversation. In Part One, I introduce, or reintroduce, and then endorse, a definition of civil rights put forward by Thomas Paine over two hundred years ago, well before the idea of "nondiscrimination" had taken hold, in his famous and indeed iconic pamphlet Rights of Man. ${ }^{18}$ "Civil rights," Paine argued in that world-changing document, are, first, "natural rights"-by which he meant that they are rights that attach by virtue of our humanity, ${ }^{19}$ what we today sometimes call "human rights" and what were then sometimes called "fundamental rights." But, he went on to explain, natural rights and civil rights are not coterminous, for two reasons. First, while natural rights attach to a man by virtue of his humanity, civil rights, Paine argued, are those natural rights that distinctively attach not just by virtue of his humanity, but also by virtue of his "member[ship]

\footnotetext{
17 See, e.g., Robert D. Putnam, Bowling Alone: The Collapse And Revival of AMERICAN COMMUNITY (2001).

18 Thomas Paine, Rights of Man (Penguin Books 1984) (Part One first published 1791, Part Two first published 1792).

${ }^{19} \mathrm{Id}$. at 68.
} 
in society."20 That is what makes "civil” rights civil. Second, and relatedly, "civil rights" are that subset of natural rights that a man cannot enforce on his own: rights, in Paine's own language, "to the enjoyment of which his individual power is not, in all cases, sufficiently competent." 21 Unlike the natural rights "of the mind," or of conscience, or of behavior that does not harm others, Paine argued, civil rights distinctively require the presence of the state for their perfection and enforcement. ${ }^{22}$ Civil rights, in other words, unlike other (non-civil) natural rights, are not rights from, but rather are rights to: "civil rights," distinctively, are rights to state action, to state law, to state institutions, to a functioning government, and basically, to community. Paine's definition, I will argue, penned well before the idea of a legal or constitutional right against discrimination had taken hold, may provide a better account of both our oldest and our most contemporary civil rights, than the modern idea of civil rights as simply rights of nondiscrimination. But more to the point, Paine's account highlights just the feature of civil rights - the necessity of the state, and of law, to the perfection of the rights at the heart of civil society-that we have most failed to center in our scholarship.

Paine's quite formal definition, however, does not give us much help in developing the content of our civil rights, beyond his fecund and prescient suggestion that they must include rights of "security and protection."23 Beyond re-introducing Paine, therefore, my second general goal in the first part of this essay will be to marry, or synthesize, the formal definition of "civil rights" he provided, with the modern and very substantive account of the content of "human rights" propounded by Martha Nussbaum and Amartya Sen over the last thirty years, in their exposition of the "capabilities approach" to rights and human welfare. ${ }^{24}$ The capabilities approach, as developed by Sen and Nussbaum, I believe, fills the gap in a way which is resonant with Paine's overall political philosophy: we have human rights, Nussbaum and Sen argue, to enjoy those human capabilities that are most conducive to our individual flourishing -including, for example, our "capability" for a healthy and long life, for sociability, for intimacy, for play, for cultural and intellectual engagement, and for interaction with our natural environment. ${ }^{25}$ Protection of these capabilities, and the human

${ }^{20} I d$.

${ }^{21} I d$. at $68-69$.

${ }^{22} I d$. at 68 .

${ }^{23} I d$.

${ }^{24}$ See Martha C. Nussbaum, Nature, Functioning, and Capability: Aristotle on Political Distribution, in OXFORD STUdies IN ANCIENT PhILOSOPHY 145 (supp. vol. 1988); Martha C. Nussbaum, Human Functioning and Social Justice: In Defense of Aristotelian Essentialism, 20 Poli. TheOry 202 (1992); Nussbaum, supra note 16; Martha C. Nussbaum, Capabilities as Fundamental Entitlements: Sen and Social Justice, 9 FEMINIST ECON. 33 (2003) [hereinafter Nussbaum, Capabilities as Fundamental Entitlements]. See also AMARTYA SEN, Rights and Capabilities, in ResourCes, VAlues And DEVElopment 307 (3rd prtg. 1998); Amartya Sen, Commodities and Capabilities (1999); Amartya Sen, Well-being, Agency and Freedom: The Dewey Lectures 1984, 82 J. PHIL. 169 (1985); Amartya Sen, Capability and Well-Being, in THE QUALITY OF LIFE 30 (Martha C. Nussbaum \& Amartya Sen, eds., 1993).

${ }^{25}$ Nussbaum, Capabilities as Fundamental Entitlements, supra note 24 at 36-42; SEN, COMMODITIES AND CAPABILITIES, supra note 24 at 17-21. 
flourishing they nurture, may, sometimes, require that the state leave us alone and let us develop and enjoy our capabilities according to our own lights, without interference from an overly intrusive community or censorial state actors. Often, though-more often, in factthe individual flourishing that Sen and Nussbaum identify as the end of human welfare requires a state actively promoting those fundamental capabilities that produce it. States, therefore, sometimes have an obligation to promote and protect those capabilities, as well as an obligation to sometimes leave them be, and individuals have rights - human rights - to states that do both.

The various human capabilities Sen and Nussbaum identify which require active state promotion and protection, rather than state restraint, suggest the premises of a moral argument for Painean civil rights, as well as a foundation for at least some of the interests protected against discrimination by our Civil Rights Acts, of both centuries. At the same time, a (modified) Nussbaum-Senian “capabilities approach” to welfare and rights suggests a moral argument for those civil rights we might believe we should have, but do not yet fully enjoy: rights to decent work that is safe, meaningful, and fairly compensated, rights to greater community support for parents caring for young children or grown children caring for sick or dying parents, a high quality education that prepares us for citizenship as well as gainful employment, a trustworthy and effective police force that protects us against violence without violating our rights of privacy and dignity, and so on. I will therefore try to supplement Paine's bare-boned account of the political logic of civil rights-how and where they fit, so to speak, in the pantheon of natural, fundamental, legal and constitutional rightswith Nussbaum and Sen's rich, substantive account of human welfare and what states are obligated to do to promote it. This blended account, I will conclude, suggests what is distinctive about "civil rights" against the backdrop of our legal rights and human rights both. Against the former, civil rights are those legal rights that promote fundamental human capabilities, and protect our enjoyment of them against unjust impediments, including public and private discrimination. Against the latter, civil rights are those natural rights which, more specifically, attach by virtue of membership in society, which a man cannot enforce on his own and therefore require active state involvement for their protection, much as Paine argued two centuries back.

Putting this together, I will ultimately argue in the first part below that "civil rights" are rights to be free of unjust impediments, such as, as per the '64 Act, public or private discriminatory practices, to the underlying rights we all should enjoy to some set of legally constructed or legally protected social goods or institutions - private property, contractual freedom and powers, dignified and fairly compensated labor, public accommodation and transportation, high quality public education, civil marriage, family life, and religious practice, among others - which both facilitate participation in civic life and permit us to enjoy our most fundamental human capabilities. So, my claim will be that "civil rights," jurisprudentially, are those rights which give us access to the legal apparatus of civil life, which in turn facilitates the enjoyment of basic, universally-shared, human capabilities. I will sometimes call my account a Painean-Nussbaumean, or Painean for short, account of the jurisprudential nature of a civil right. In the first part of this essay I will argue that the Painean account illuminates features of the Civil Rights Act and shows its continuity with other civil rights we possess or should possess, as well as with civil rights movements from our history. 
In Part Two I elaborate a bit on my constructed Painean conception of civil rights by contrasting civil rights, so understood, with what I believe is an emerging and new paradigm of constitutional rights, which I have called, elsewhere, "exit rights." ${ }^{26}$ These relatively new and newly constitutionally recognized “exit rights,” I will argue briefly here, and have argued at length elsewhere, are not classically individual rights, justified on traditionally liberal grounds; they are not simply rights to enjoy some measure of privacy, or religious freedom, or freedom of conscience, or to individuate ourselves in some other way, within civil society. Rather, exit rights, which include, inter alia, the rights to own and use a gun in self-defense, to procure an abortion, to die, to homeschool one's children, to not purchase health insurance, and, possibly, the rights of religious corporations or non-profit entities to exemptions from the mandate of antidiscrimination laws, are radically libertarian rights to effectively "exit" civil society, the social contract, or some substantial part of it. Our "civil rights," understood in the Painean sense, by contrast, can fairly be called "rights to enter" that compact, or to garner the benefit of it, and to do so, specifically, through accessing some aspect of its legal architecture. The exit rights increasingly protected by the Constitution, as construed by our courts, are rights to exit the same civil society to which civil rights protect entrance. Constitutional rights and civil rights, then, contrary to the claims of a number of constitutional law theorists, are not only not the same thing and not mutually constitutive of our "fundamental law," but they are more often than not, these days, on a collision course.

The contrast between civil and constitutional rights that I will explore in Section Two below is at heart aesthetic and ethical. Our relatively new array of constitutionally-inscribed "exit rights" have, I will suggest, a tragic arc. As in the last act of a classic or Shakespearean tragedy, their exercise often culminates with characters splayed dead across the stage: individuals exercising their rights to die, to kill, and to abort are, after all, severing earthly as well as communitarian coils; they are all dealing in death. Even when not lethal, however, the exercise of an exit right culminates almost invariably in the spectacle of an isolated individual, shrouded in his various constitutional rights to be left alone, with the community from which he is so willfully estranged, in shatters. The intruder is killed by the homeowner, rather than captured by a trustworthy constable; the fetus is expunged, rather than borne into a supportive community; the child is educated in isolation at home, rather than at a public school and in a community of peers; the suicidal patient is dead, rather than cared for in hospice. Civil rights have, by contrast, what I call a "comedic arc.” As in Shakespearean and classical comedy, the exercise of a civil right culminates in a communal ritual or event, such as a couple's wedding celebration, where they are joined by their community's representatives of faith and state, or a new day in a well-functioning and integrated schoolroom or workplace, or the cure of an illness and restoration to health, financed by a community of co-insureds who have spread and shared risks, or the joyous arrival of a new birth accompanied by responsible attendant care, not threatened by the specter of a lost job. In the last act of a comedy, the state, as well as the community and its worth are reconfirmed, and the individual's role within it, as well as his distinctiveness from it, is celebrated. Part Two below draws the obvious inference that centering comedic civil rights, rather than the

${ }^{26}$ Robin L. West, Tragic Rights: The Rights Critique in the Age of Obama, 53 WM. \& MARY L. REV. 713 (2011) [hereinafter West, Tragic Rights]; Robin West, Exit Rights: Roberts' Conception of America in the ACA Decision, JURIST-FORUM, July 26, 2012, http://jurist.org/forum/2012/07/robin-west-aca-roberts.php\# [hereinafter West, Exit Rights]. 
tragic constitutional rights we have obsessed over for the last thirty years, in our understanding of rights and in our ongoing attempts to take them seriously, might give us a more balanced jurisprudence, and a sliver of hope for a more balanced community likewise.

The conclusion revisits the Trayvon Martin killing, and its aftermath, in light of some of these distinctions.

\section{Tom Paine's Civil Rights}

According to an influential and much quoted definition provided in Thomas Paine's canonical late eighteenth century essay Rights of Man, "civil rights" are those natural rights that are owed by a government to the people - all of them - by virtue of their membership in civil society. ${ }^{27}$ "Civil rights," Paine held, are a subspecies of "natural rights" — a claim repeated and embraced-indeed insisted upon-by proponents of the 1866 Civil Rights Act, three quarters of a century after Paine wrote. ${ }^{28}$ Natural rights, in turn, are rights we enjoy solely by virtue of our humanity; we hold them regardless of the accident of the geographic details of our birth. We hold them against our own sovereign, whether or not he recognizes them, and would hold them likewise against any sovereign. And we all hold them, Paine thought, slaves and American Indians no less than free men. ${ }^{29}$ That "natural rights" underpinning of our civil rights and civil rights tradition is no historical relic; it is, rather, a vital connection between both the reconstruction and revolutionary era use of the phrase and our modern antidiscrimination law today. From the very beginning, civil rights have been grounded in natural rights, meaning they are owed everyone, without regard to race, sex, disability and so on-again, they are owed by virtue of one's humanity. By virtue of their origin as natural rights, civil rights have always connoted some version of an antidiscrimination norm.

Civil rights were not, however, viewed by Paine and his contemporaries as coterminous with the natural rights which man possesses by virtue of his humanity, when both phrases were part of the ordinary vocabulary of lawyers and constitutionalists. Rather, they were a subset, with two characteristics differentiating them from the larger class of natural rights, of which, again, they are a part (all civil rights are natural rights, all natural rights, however, are not civil rights). First, civil rights, unlike other natural rights, are rights that attach by virtue of one's “member[ship] in society," rather than solely by virtue of one's humanity. But second, although civil rights originate as natural rights, Paine explained, unlike some of those natural rights, such as rights to the mind and conscience, or rights to behavior that does not harm others, "civil rights" are those rights that cannot be perfected by individuals standing alone, so to speak, or outside civil society and law: ${ }^{30}$

Natural rights are those [rights] which appertain to man in right of his existence. Of this kind are all the intellectual rights, or rights of the mind, and also all those rights

\footnotetext{
${ }^{27}$ PAINE, supra note 18, at 68.

${ }^{28}$ See generally Mark Tushnet, Civil Rights and Social Rights: The Future of the Reconstruction Amendments, 25 LOY. L.A.L.REV. 1207 (1992).

${ }^{29}$ PAINE, supra note 18, at 66.

${ }^{30} \mathrm{Id}$. at 68.
} 
of acting as an individual for his own comfort and happiness, which are not injurious to the natural rights of others. Civil rights are those which appertain to man in right of his being a member of society. Every civil right has for its foundation, some natural right pre-existing in the individual, but to the enjoyment of which his individual power is not, in all cases, sufficiently competent. Of this kind are all those which relate to security and protection. ${ }^{31}$

Civil rights, then, to the founding generation, at least if Paine's understanding was representative, were natural rights that require, distinctively, civil society, including positive law and legal institutions both, for their perfection. Unlike other natural rights, we can't enforce civil rights on our own. We need the affirmative assistance of positive law. So defined, "civil rights" included, for Paine, quintessentially, those rights pertaining to protection of the physical security of the individual. The security of and protection of the physical body are examples, then, of foundational rights that are only imperfectly, at best, enforceable through self-help. We "trade in" our natural rights to self-protection and security, so to speak, for the "civil right" of the protection of our physical security by the state.

How does Paine's account of "civil rights" - penned long before the civil rights acts of either of the two centuries following, and before the idea of antidiscrimination as an actionable wrong had gained traction — as "natural rights" that "appertain to man in right of his being a member of society" but "of which his individual power is not, in all cases, sufficiently competent" ${ }^{32}$ stand up, as a jurisprudential account of civil rights, both those passed into law fifty years ago, and in various statutory provisions both before and since? Better, I think, than our current lawyerly equation of "civil rights" with "antidiscrimination rights." At least echoes of Paine's definition can be heard not only in the Civil Rights Act of 1964, but in virtually all of the various civil rights acts and movements, of both the nineteenth and twentieth centuries. Thus, according to the framers and advocates of the seminal Civil Rights Act of 1866, "civil rights" include rights to enter and enforce contracts; to buy, hold, rent, and sell property; to sue, be parties, or give evidence in judicial proceedings; and to enjoy the protection of the state and its laws pertaining to the security of persons and property ${ }^{33}$-all of which fit readily Paine's description of civil rights as that subset of natural rights that should attach by virtue of membership in society, and that require legal definition and institutions to perfect. These "civil rights," as they were then called (in part to distinguish them from "political rights," such as rights to vote or serve on juries) clearly required positive law for their perfection - the power to make and enforce contracts requires contract law, enjoyment of property obviously requires property law, rights to sue and give evidence require the law of procedure, rights pertaining to the security of persons and property require the criminal law, and so forth. As such, these civil rights, which had long been granted by law to white men through the combined effect of common law or

\footnotetext{
${ }^{31} I d$.

${ }^{32}$ Id

${ }^{33}$ Civil Rights Act of 1866, ch. 31, § 1, 14 Stat. 27 (1866).
} 
statute, should, according to the framers of the nineteenth century Civil Rights Act of 1866, be granted to African Americans as well. ${ }^{34}$

The Civil Rights Act of 1871, one of the "enforcement acts" passed in the wake of the Reconstruction Amendments and popularly known as the Ku Klux Klan Act, explicitly added personal security from various private conspiracies to commit, among other wrongs, acts of domestic violence to the list of civil rights to be enforced by the federal government, rather than state militias. ${ }^{35}$ Here too, the extension fits Paine's understanding. The civil and natural right to be protected against private violence had been granted to some, by the criminal laws prohibiting it and their enforcement by state authorities, but that protection had not been extended to the protection of the freed slaves against private conspiracies contemplating violence (such as lynchings) against them; thus, the need for the Ku Klux Klan Act. The civil right to protection against private violence, according to the framers of that Act, must be extended to freed slaves. For the authors of the constitutionally doomed Civil Rights Act of 1875, "civil rights" also included the right to use public accommodations such as hotels and restaurants and to employ public transportation, and to enjoy and participate in public amusements such as in theatres. ${ }^{36}$ Here as well, these rights to participate sociably in these public spaces of civil society, which attach by virtue of membership in that society, require law for their creation and enjoyment, and the Act of 1875 created a nondiscrimination right to enjoy those participatory rights. The 1875 Act as well, then, fits Paine's definition. The major Civil Rights Acts of the nineteenth century all put into law an inclusive, universalist, and profoundly Painean impulse: to ensure that civil rights - to contract, own property, sue for private wrongs, enjoy the state's protection against violence, and make use of public accommodations - that had been granted to some, would be guaranteed to all, conditioned solely on one's membership in civil society rather than on one's racial heritage or one's earlier identification as free or slave.

In the twentieth century, the phrase took on new meanings, but nevertheless held close to the jurisprudential core of Paine's definition. Virtually all of our twentieth century civil rights - both those recognized in law, and those still fought over — can easily be described as natural rights that attach, or should attach, both by virtue of one's humanity and one's membership in civil society, but which cannot be enforced by an individual standing alone. Thus, as told in Risa Goluboff's groundbreaking scholarship from ten years ago, ${ }^{37}$ but as intimated as well in much of William Forbath's early work, ${ }^{38}$ the idea of "civil rights" in the post-Lochner era included, foundationally, labor rights, including not only rights to be free of peonage and involuntary servitude, derived directly from the Thirteenth Amendment, but also, eventually, the right to join a union and to strike, as well as rights to minimum

\footnotetext{
${ }^{34} \mathrm{Id}$

${ }^{35}$ Ku Klux Klan Act, now codified as 42 U.S.C. § 1985 (2013). The Act holds, in part, that when two or more persons "conspire or go in disguise on the highway or the premises of another, for the purpose of depriving ... any person or class of persons of the Equal Protection of the Law," they may be sued. See Griffin v Breckenridge, 403 U.S. 88 (1971). ${ }^{36}$ Civil Rights Act of 1875, Ch. 114, 18 Stat. 336 (1875) (held unconstitutional in The Civil Rights Cases, 109 U.S. 3 (1883)).

${ }^{37}$ Goluboff, Lost Promise, supra note 2; Goluboff, Thirteenth Amendment, supra note 2.

${ }^{38}$ See e.g., Forbath, Caste, supra note 3; Forbath, Past and Future, supra note 3.
} 
wages and safe work conditions. ${ }^{39}$ Participation in the labor economy as a free and equal citizen, Goluboff shows, was viewed as key to a shared civic life, according to the New Dealinspired Justice Department-housed lawyers of the 1940s Civil Rights Section, and who were responsible for giving content and meaning to the "civil rights" they were charged to enforce. ${ }^{40}$ This usage continued in popular discourse throughout much of the century: as late as 1968, Martin Luther King himself spoke of rights to jobs, to strike, to organize, and to unionize as "civil rights" and scores of labor activists since have followed suit. ${ }^{41}$

In a now much-studied history, during the middle and second half of the twentieth century, the content of "civil rights" shifted from labor rights per se to rights of minorities to enjoy employment and educational opportunities free of discrimination, and it was during this time that the lawyerly identification of "civil rights" with "antidiscrimination rights" apparently took hold, at least according to historians of the era. ${ }^{42}$ Here as well, though, the underlying civil rights - to employment and education opportunities — no less than the underlying nineteenth century civil rights of contract, property, security, and access to civil justice-are fairly described as natural rights owed to individuals by virtue of their membership in civil society and cannot be enforced by individuals standing alone. Fair employment and decent education both are social institutions that are heavily dependent upon an array of laws, both statutory and common, for their realization. In the last few decades, by dint of at least occasional if not common usage, the phrase "civil rights" is sometimes understood as including various statutorily or constitutionally created rights that facilitate family life, such as the "right to marry" without regard to sexual orientation; ${ }^{43}$ the right to family or medical leave from work necessitated by the birth of a child or the illness of a family member, as protected by the Family Medical Leave Act (FMLA); ${ }^{44}$ the right to be free

${ }^{39}$ Goluboff, Thirteenth Amendment, supra note 2, at 1616-18.

${ }^{40} \mathrm{Id}$.

${ }^{41}$ Reverend Martin Luther King, Jr., I Have a Dream . . ., Speech at the "March on Washington” (Aug. 28, 1963) (transcript available at http://www.archives.gov/press/exhibits/dream-speech.pdf).

4242 U.S.C. $\S \S 2000 a, 2000$ e (2013); 20 U.S.C. $\S \S 1681-88$ (2013). See, e.g., Goluboff, Thirteenth Amendment, supra note 2, at 1619; Mack, Rethinking Civil Rights, supra note 14, at 331-33.

${ }^{43}$ Loving v. Virginia, 388 U.S. 1 (1967), is typically cited for the proposition that the right to marry is a civil right, but for an assessment of the right to marry without regard to sexual orientation, see United States v. Windsor, 133 S.Ct. 2675 (2013); Goodridge v. Dep’t of Pub. Health, 798 N.E.2d 941 (Mass. 2003). The struggle for marriage equality for same sex couples is often referred to as the "Last Great Civil Rights Struggle.” See, e.g., Lauren Rankin, Supreme Court Gay Marriage: Is Marriage Equality Really the Last Civil Rights Struggle?, TRUTHOUT (June 16, 2013), http://www.truth-out.org/opinion/item/17007supreme-court-gay-marriage-is-marriage-equality-really-the-last-civil-rights-.

${ }^{44}$ The Family Medical Leave Act (FMLA) is widely understood as a civil right, as is the Violence Against Women Act (VAWA). Both laws can be construed as antidiscrimination rights-FMLA can be read as conferring a right not to be discriminated against in the workplace by virtue of one's status as a caregiver, and VAWA as conferring a right to protection against violence, regardless of gender. Both, however, are also clear examples of civil rights statutes that convey rights to underlying substantive rights, and not just rights 
of intimate violence, as protected by the Violence Against Women Act (VAWA); ${ }^{45}$ rights derived from various sources to a high quality as well as integrated public education, as imperfectly echoed in statutes such as No Child Left Behind (NCLB) ${ }^{46}$ and the Individuals with Disabilities Education Act (IDEA); ${ }^{47}$ as well as a right to health care, the existence of which is strongly suggested by the Affordable Care Act (ACA). ${ }^{48}$ Here too, the underlying natural rights - to family, parentage, marriage, safe intimacy, quality education, and access to health care - are owed to all of us by virtue of societal membership. And, here as well, they are rights that cannot be enforced by any individual without the aid of considerable positive law. They all look like Painean civil rights.

Thus, all of these early-, mid- and late-twentieth and early-twenty-first century civil rights laws, or in some cases, still unfinished civil rights campaigns recognize, create, advocate for, or protect civil rights that loosely fit Paine's definition. Most, although not all, protect those civil rights against some form of race, sex, disability, age, or sexuality discrimination. What they all do, though, is protect various civil rights against some sort of unjust social ill-either discrimination, poverty, joblessness, lack of insurance, private violence, or unequal allocations of unpaid intimate labor, with its consequent disparate impacts in workplaces - that in turn hampers enjoyment of underlying civil rights. In all of them, the underlying "civil right" protected against these pernicious forces is a right to engage or participate in some aspect of civil society-employment, education, marriage and family life, access to health care, physical security and the mobility that goes with it, contract exchanges, and ownership of property - that is in turn facilitated through legal processes. And in all of them, again echoing Paine, the underlying right that is being protected, extended or guaranteed, is not simply natural, although it is that —a right that should attach to one by virtue of one's humanity-but it is also, distinctively, civil-it attaches or should attach by virtue of one's membership in society.

Let me try to extract four definitional principles of the jurisprudential nature of a “civil right” from this application of Paine's definition of civil rights to the examples

against wrongful or irrational classification: FMLA protects the right to not lose a job by virtue of caregiving responsibilities, and VAWA protects the right to meaningful protections against intimate violence. Family Medical Leave Act (FMLA), Pub. L. 103-3, 107 Stat. 6 (1993) (codified as amended in scattered sections of 5 and 29 U.S.C.); Violence Against Women Act (VAWA), Pub. L. No. 103-322, tit. IV, 108 Stat. 1902 (1994) (codified as amended in scattered sections of 8, 16, 18, 28, and 42 U.S.C.). See, e.g., Johanna R. Shargel, In Defense of the Civil Rights Remedy of the Violence Against Women Act, 106 YALE L.J. 1849 (1997).

${ }^{45}$ Violence Against Women Act (VAWA), Pub. L. No. 103-322, tit. IV, 108 Stat. 1902 (1994) (codified as amended in scattered sections of 8, 16, 18, 28, and 42 U.S.C.).

${ }^{46}$ No Child Left Behind Act of 2001 (NCLB), Pub. L. 107-110, 115 Stat. 1425 (codified as amended in scattered sections of 20 U.S.C.). See also Brown v. Bd. of Educ., 347 U.S. 483 (1954) (education as a civil right).

${ }^{47}$ Education of the Handicapped Act (now Individuals with Disabilities Education Act (IDEA)), Pub. L. 91-230, 84 Stat. 175-188 (codified as amended in scattered sections of 20 U.S.C.).

${ }^{48}$ Patient Protection and Affordable Care Act, Pub. L. 111-148, 124 Stat. 119 (codified as amended in scattered sections of 21, 25, 26, 29, and 42 U.S.C.). 
surveyed above, of the rights protected by our various Civil Rights Acts. First: a civil right is a natural right, meaning it is a right that attaches by virtue of one's humanity. In contemporary terms, we might restate the same point in this way, drawing on Sen and Nussbaum's universalist account of human wellbeing: civil rights, like all natural rights, protect or nurture our fundamental "human capabilities" - the capabilities we have, by virtue of being human, for long and healthy lives, for cultural and intellectual engagement, for play, for interacting with our natural environments and so on-enjoyment of which are the preconditions, universally, for living a good life. ${ }^{49}$ Some of those human capabilities, of course, are nurtured by familial direction during childhood and then furthered and directed by individual effort. They require nothing more than benign neglect from the state for their flowering. Some of them are also, though, furthered by social institutions and the laws that structure them, and some of them are fully dependent on those social institutions and laws. ${ }^{50}$ Thus, our capability for health and longevity is furthered not only by a sensible diet and plenty of exercise growing up in a healthy household, but also by access to health care throughout life. ${ }^{51}$ Our capability for mobility and physical freedom is furthered not only by strong limbs developed by natural and healthy maturation, but also by protection against violence and the policing that provides it; our capability for intimacy, not only by the flowering of private lives that seek it and the emotional health that sustains it, but also by the promise of a family life that will be protected by sound policing against external threat and internal abuse; our capability for sociability not only by a natural capacity for language, but also by access to our legally structured public accommodations and public spaces; and our capability for a stimulating mental life in adulthood not only by being left alone to discover (or not) Pythagorean theorems on our own, but by a high quality public education, with sound curriculum and pedagogy, and the law that structures it. The "civil right," in all of these cases, is the right to access those institutions and to enjoy the laws that structure them, which protect and nurture these natural capabilities. The various civil rights acts, in turn, provide that those rights cannot be discriminatorily denied.

The '64 CRA itself, of course, directly and explicitly guarantees rights to some of the legal structures that facilitate various capabilities, notably, for employment opportunities, education, sociability, and community. These capabilities are quite directly furthered by fair jobs offered at nondiscriminatory wages, the hospitality of restaurants and hotels and the convenience and mobility of public transportation, decent educational opportunities, and the buying and selling of property to allow for both mobility and choice of residence but also the enjoyment or production of consumer goods. The same relation holds, though, for our newer civil rights. The Affordable Care Act directly protects, through a complex regime of rights

\footnotetext{
49 Nussbaum presents the "capabilities approach” as an alternative to a human rights approach, but also makes clear that the two are consistent and mutually supportive, and that the former leaves room for the latter, where a sense of imperativism is desired. NuSSBAUM, WOMEn AND Human DeVELOPMENT, supra note 16, at 96-98.

${ }^{50}$ In more conventional terms, some of the capabilities are best protected by negative rights, and some by positive.

${ }^{51}$ For a related approach, see MAdisOn Powers \& RUTH FAdEN, SOCIAL JUSTICE: THE Moral Foundations of Public Health and Health Policy (2d ed. 2006); see also my review, Robin L. West, Book Review: Social Justice: The Moral Foundations of Public Health and Health Policy, 10 DePaul J. Health Care L. 567 (2006).
} 
and responsibilities, the individual capability to live a healthful life, ${ }^{52}$ while NCLB and the IDEA $^{53}$ protect, again through rights, the fundamental capacities we all share for exploring the world and enjoying a lively mental and cultural life. The Family and Medical Leave Act (FMLA) ${ }^{54}$ encourages our capabilities for both work and family, and state gun safety laws and the Violence Against Women Act (VAWA) ${ }^{55}$ aim to do the same for our capabilities for intimacy, mobility, physical security, safe sociability, and freedom from fear. All of these are human capabilities that are essential to a good life, on Nussbaum and Sen's account, and all of these capabilities are protected through the social and civil life that law and society both aim to structure. Our civil rights can be understood as the rights to enjoy the fruits of all of that law, and our civil rights acts understood as laws that guarantee that those civil rights will not be discriminatorily denied.

My second principle also tracks Paine: "civil rights" are natural rights that attach not only by virtue of man's humanity, but also by virtue of his "member[ship] in society." Briefly: civil rights center our rights to participate in community, rather than rights to be free from it. Professor Rebecca Zeitlow is entirely right, for just this reason, to refer to the antidiscrimination rights created by the 1964 Civil Rights Act as "rights of belonging.", 56 Antidiscrimination rights that attach by virtue of one's "member[ship] in society," as Paine put the point, are "rights of belonging,” in Zeitlow's near-biblical usage.

The point can, however, be substantially broadened, beyond Zeitlow's intended meaning. It is not only the antidiscrimination rights created by the '64 Act that can be fruitfully described as "rights of belonging," for two reasons. First, the underlying civil rights protected against discrimination by both the '64 CRA as well as the various civil rights acts that came after it are themselves "rights of belonging." They are all rights to "belong to," or participate in, various communities: communities of employers and employees, of landlords and tenants, of buyers and sellers, of students, of teachers and administrators, and of neighbors and officials in polling places. The Acts protect the civil rights of workers, buyers, sellers, tenants, voters, citizens, students, teachers, producers, and consumers to participate in these various communal workplaces, neighborhoods, markets, schools, city halls, courthouses, sites of public gathering and transportation, and voting sites, and to do so through accessing the legal forms, rules, and entitlements that structure those locales. As Zeitlow argues, the nondiscrimination right those acts create brings people together in real space and time. ${ }^{57}$ They do not just create an abstract right in an individual to be free of an invidious discriminatory intention in the minds of state actors: the antidiscrimination rights originating in civil rights acts prohibit policies that adversely impact actual rates of

\footnotetext{
52 Patient Protection and Affordable Care Act, Pub. L. 111-148, 124 Stat. 119 (codified as amended in scattered sections of 21, 25, 26, 29, and 42 U.S.C.).

${ }^{53}$ NCLB, Pub. L. 107-110, 115 Stat. 1425 (codified as amended in scattered sections of 20 U.S.C.); IDEA, Pub. L. 91-230, 84 Stat. 175-188 (codified as amended in scattered sections of 20 U.S.C.).

${ }^{54}$ FMLA, Pub. L. 103-3, 107 Stat. 6 (codified as amended in scattered sections of 5 and 29 U.S.C.).

${ }^{55}$ VAWA, Pub. L. No. 103-322, tit. IV, 108 Stat. 1902 (codified as amended in scattered sections of $8,16,18,28$, and 42 U.S.C.).

56 Zietlow, supra note 14, at 946.

${ }^{57}$ Id. at $990-91$.
} 
participation and encourage or mandate affirmative actions and related remedies that aim directly for more inclusive workplaces and neighborhoods. But the same is true of the underlying civil rights themselves. The civil rights protected against discrimination by the civil rights acts, in other words, and not just the antidiscrimination norm itself, concern the terms of our actual communal interactions with each other; they are not about the terms of our individual relationship with the minds of state actors. They aim to bring us together contractually, educationally, civilly, and so on. The aim of those laws in toto, then, is a participatory community, by virtue of not only the antidiscrimination norm but also the underlying rights. All of those rights seek to build trust between classes of strangers once indifferent or implacably hostile, and all do so, toward the end of strengthening the community's civic bonds.

Zietlow's provocative metaphor - that the civil rights of the CRA are "rights of belonging" 58 _ can be extended in a second direction as well. Other rights won or fought for as "civil rights" in our history, outside the parameters of those acts, and whether protected against the pernicious effects of discrimination or some other social ill, can also be described as "rights of belonging." The civil right to form a labor union and to decent wages for safe labor, for example, prompted by the labor struggles of the nineteen teens, twenties, and thirties, were "rights of belonging," aiming for a more decent, fair, and democratically participatory workplace. Those rights contrasted-and in ways that parallel the contrast between the constitutional and statutory antidiscrimination norms — with the bare and sterile right to "individual liberty" presupposed by rights to contract: contract rights, at best, create freer individuals, unbound by paternalistic states, and empowered, at least in theory, to set terms and conditions of their own individual employment by virtue of their power to exit.

The Family and Medical Leave Act directly aims to strengthen actual communities in the home and in the workplace by pooling the costs of early infant care or the care of sick family members, and the ACA likewise strengthens ties of responsibility among those who share risks in insurance pools. Gun control laws aim to build on mutual trust, rather than rely on MAD-styled individual antagonism to protect us each against the threat of violence posed by each other, and VAWA aims to protect physical security similarly, toward the end of enhancing the protection of women's mobility and safety in the communities of home and civil life. NCLB- and IDEA-styled laws aim for stronger communities, both in schools and in neighborhoods that indirectly benefit from the floor of quality they establish, rather than leaving parents and their children to their own individualistically fashioned means, needs, and desires. Some of these laws can be (and have been) fairly described as antidiscrimination laws-VAWA corrects prior discriminatory policing policies, FMLA corrects an indirect form of gender discrimination on the job, IDEA corrects for prejudicial educational policies against children with learning disabilities. But they obviously cannot be simply described as antidiscrimination laws, and they might not be best described in that way. VAWA most directly targets violence against women, not discrimination against them; IDEA aims to educate, not eradicate invidious distinctions; and FMLA likewise directly aims to support parents, rather than abolish discrimination against women on the job. All of these laws, whether or not they can fairly be described as antidiscrimination norms, aim, quite directly, to strengthen civic, communal, or neighborly bonds.

${ }^{58} I d$. 
Third: civil rights distinctively aim to protect those individual fundamental capabilities that are facilitated by law, and which, as per Paine, cannot be perfected, or enforced, by the individual standing alone. The "civil right" is a positive right of access to the laws, legal structures, legal forms, and legal entitlements that in turn protect or nurture fundamental capabilities that cannot be protected without societal and civil interaction, encouragement, or involvement. So, the civil rights acts of both the nineteenth and twentieth centuries empower individuals who would be otherwise barred by dint of private discrimination, from various social institutions that depend upon civil society, and its law, for their very definition: buying and selling property, contracting for and then occupying hotel rooms, eating in restaurants, and working at jobs under the same terms as white co-workers.

Likewise, the Accordable Care Act protects the human capabilities of health and longevity through pooling risk and thereby ensuring improved health, which is facilitated not by individual effort but by an intricate and interpersonal jurisprudence interweaving statute, contract, and property law. Gun safety laws and the Violence Against Women Act protect the individual capabilities of safety, intimacy, and mobility, by seeking to limit the isolating fears and inhibitions associated with excessive private violence, and do so through a set of laws and legal institutions, rather than through arming everyone, or engaging in exhortations toward individual empowerment. The Family and Medical Leave Act protects individual capabilities both for work and family life, not through cheerleading heroically individualized parenting - exhorting us all to "lean in"-but through mandated employer-provided assistance with the costs of childcare. The underlying individual capabilities in all of these cases require legal structures, law, and social institutions, not just unimpeded individual initiative. Without the ACA, our ability to live a healthy life is frustrated by poverty that prevents the purchase of insurance; without FMLA, our ability to care for dependents and remain employed - our ability to participate in both family and work life - is hampered by our inability to share the burden of caring for newborns; without gun control laws, our ability to move freely through our neighborhoods is hampered by our fears for our own physical security; without education laws, our abilities to participate in high culture as well as in an educated workforce and public sphere is severely limited by ignorance and illiteracy. We can't do any of this on our own, basically, and, per Paine, that is where and why civil rights enter the picture.

Finally, civil rights are aspirational, rather than positivistic. They are not a listing of what the state has provided through law. Rather, they are rights the state should protect, even if it does not. The positivistic civil rights we have, in other words, are an imperfect and incomplete recordation of the civil rights we are owed. Thus, while we have perfected, more or less, the right to contract, which the 1866 Civil Rights Act aimed to guarantee to freed slaves as well as white men, we have clearly not perfected, in our labor law, a fully recognized legal right to good and decently paid labor. ${ }^{59}$ We may have a "civil right," then, to a decent job at decent wages, but we clearly don't have a legal right to one. Quite the contrary: the antidiscrimination right to employment opportunities exists against the backdrop of an employment-at-will regime that in fact guarantees very much the opposite. Likewise, we may have a "civil right" to a high quality education, as evidenced, in part, by the rhetoric and justifications given our rights to "individualized educational plans" if we suffer disabilities, our rights "not to be left behind” if we suffer impoverished school

${ }^{59}$ Civil Rights Act of 1866, ch. 31, § 1, 14 Stat. 27 (1866). 
placements, and the inclusion of a constitutional right to a good education in most state constitutions which guarantees some measure of intra-state-although not inter-stateequality. But we do not have a secure and legally-recognized legal right to a high quality education across the board. We may have a civil right to health care, as evidenced in part by a right we now have to purchase insurance at reasonable rates under the Affordable Care Act, but that is obviously a highly contingent as well as contested and vulnerable right: we do not have a robust legally recognized right to either health or health care. We have various legal rights under the Violence Against Women Act, but we do not yet have anything like a full recognition of a civil right to be free of intimate violence. Yet, the civil rights to employment, education, safe intimacy, and health, are nevertheless the aspirational rights that we "have," even if only imperfectly secured by these statutes.

Now, let me contrast this conception of civil rights-Paine's understanding, basically - with the conventional, and truncated, understanding of a civil right that I believe wrongly dominates our civil rights conversations. Civil rights, as I believe they should be defined, facilitate forms of individual participation in the civic community that promote fundamental individual capabilities, such as our capabilities for intimacy, work, physical security, health, engagement in mental and cultural life, and neighborliness, and they do so through guaranteeing access to the laws that structure the civic institutions that promote or protect them. Rights to contract, property, employment, and so on facilitate participation in aspects of civic life that enhance our individual capabilities for work, family, health and sociability. Civil rights to nondiscrimination guarantee that access to those rights is equally shared, regardless of race and gender. This much of the Painean view is consistent with what I have labeled the conventional view.

The differences, however, are significant. First, and as I have stressed throughout, the Painean conception, unlike the traditional, centers rather than ignores the content of the underlying civil rights protected by the antidiscrimination norm: rights to contract, employment opportunities, education, and so on. Second, the Painean conception is aspirational, meaning rooted in natural as well as positive law: the civil rights we have are those rights we should have, not just the rights we have already won. Our civil rights are not exhausted by the rights to contract, property, employment, and educational opportunities protected by extant Civil Rights Acts, but also include rights to marriage, physical security, safe intimacy, health and longevity, and participation in family life, and our capacity for meaningful work, all of which are intimated but nevertheless only imperfectly protected by existing law. Third, and as I will elaborate below, civil rights, so understood, are neither constitutional rights nor quasi-constitutional rights: their recognition might be necessary to further particular constitutional guarantees, but their meaning, their reach, and their jurisprudential implications are not defined or limited by those guarantees or the constitutional texts that provide them. They are determined by our nature, not by our law, constitutional or otherwise. Fourth, “civil rights” so understood, are rights to the state support, state law, and state institutions that are necessary to their enjoyment. Under the Painean view as I have constructed it here, this positivity is a central feature of those rights definitionally, rather than an awkward and contingent feature that clumsily contrasts with the overwhelming negativity of the constitutional rights with which civil rights are often grouped, under the traditional view.

Lastly, the barriers to the full development of our capabilities that relate to community participation and that require law for their perfection, on the Painean conception, 
do not end with discrimination, either public or private. Poverty, poor education, poor health care, and vulnerability to violence are also barriers. Laws that seek to counter those barriers, no less than laws that seek to counter discrimination, on this understanding of the rights at the heart of "civil rights," are core, not peripheral, examples of civil rights acts. Collectively, civil rights laws all guarantee rights to which we are entitled by virtue of our membership in society. Some, but not all, do so by providing "rights to those rights," against private or public discrimination. They all, though, confer rights to participate in civic structures that are products of law: public education, public markets in insurance, secure and safe unarmed communities protected by a trustworthy police force, and structured and legally-mandated postpartum support in the aftermath of a child's birth. Laws that do so, such as FEMA, VAWA, the ACA, the FLSA, NCLB, and IDEA, whether or not they aim at discriminatory public or private conduct, are also, quintessentially, civil rights laws.

\section{Constitutional and Civil Rights: One Contrast}

Are civil rights, both those protected by the Civil Rights Acts and more generally, best understood as constitutional or quasi-constitutional rights? A number of commentators over the last ten years, including Bruce Ackerman in his Holmes lectures on the subject, have suggested, or argued, as much. ${ }^{60}$ It is easy to see why this collapsing of civil and constitutional rights is a prudentially attractive suggestion: if the passage of the Civil Rights Act can be regarded as an extended constitutional moment, and civil rights, therefore, as constitutional rights, then neither the Court nor subsequent congresses should trim them, cut them back, repeal them, or find them unconstitutional, for any but the gravest of reasons; constitutionalizing them, in effect, gives them some measure of permanence as well as stature against potentially hostile future configurations of congresses and courts. It is also a doctrinally logical suggestion, particularly if we think of civil rights as antidiscrimination rights: understood as antidiscrimination rights, civil rights, like the Court's Equal Protection doctrine, are attempts to give content to the general promises of equality embedded in the Constitution's Fourteenth Amendment. And, antidiscrimination is now the heart of the Court's Equal Protection doctrine. So: if civil rights are antidiscrimination rights, and antidiscrimination rights are constitutional rights, then, ergo, civil rights must be constitutional rights, or at least quasi-constitutional rights, as well.

It is important to note that the doctrinal syllogism just spelt out does not work: even if the framers of the Civil Rights Acts were reinterpreting Section One of the Fourteenth Amendment in devising rights of antidiscrimination, it by no means follows that that is all they were doing. And indeed, it is not all they were doing, as I hope I have already shown. There are, however, prudential reasons as well to resist what is essentially a rhetorical and strategic conflation of civil rights on the one hand with constitutional rights on the other. The major one is simply this: even if constitutional and civil rights are overlapping categories — some civil rights are also constitutional rights, and vice versa — and even though civil rights also target the inequality prohibited by the Fourteenth Amendment—which of course they do-nevertheless, there are vast differences between civil rights, at least on the Painean conception I have outlined above, and particularly our contemporary constitutional rights.

${ }^{60}$ Ackerman, supra note 14, at 1761. 
Those differences are simply obscured, or muted, if we blur the distinctions between them. Once we include within the scope of "civil rights" the underlying rights those civil rights acts protect-if, that is, we examine civil rights in the Painean sense, as to include the rights protected against discrimination, rather than just the antidiscrimination right itself-it is clear that civil rights contrast, far more than they compare, with constitutional rights, and particularly with the newly-discovered constitutional rights that have been recognized, argued for, or contemplated over the last twenty or so years. Painean civil rights and constitutional rights so understood are not only, then, not co-constitutive of constitutional law. They are also, increasingly, on a collision course, and it might be wise not to obscure that fact. Let me just draw out this contrast.

The civil rights I have focused on in this essay — both the historic nineteenth century civil rights to enjoy property, contract, physical security, public accommodations, and rights to sue for wrongs, but also our modern civil rights to a high quality publicly-funded education, family and medical leave, access to health insurance, trustworthy police protection against intimate, private, or neighborhood violence, rights to marry, and rights to decent labor and employment opportunities — are all rights to be included in a participatory public life. As noted above, Professor Zeitlow calls the antidiscrimination rights the acts created "rights of belonging"; I would say, I think more inclusively, that the civil rights protected by those antidiscrimination rights are rights to enter. They are rights to enter schoolhouses, workplaces, homes, marriages, neighborhoods, and so on. Understood as such, civil rights contrast - not compare - with a group of constitutional rights that cover much of the same lived geography, and that have been sought, recognized, or argued for over the last thirty years, and which I have elsewhere called "rights to exit": the still-contested but increasingly recognized constitutional right to homeschool one's children; ${ }^{61}$ the constitutional right to $\operatorname{die}^{62}$ and the right to not buy health insurance; ${ }^{63}$ the Second Amendment right to own a gun and use it in self defense, ${ }^{64}$ the ever-embattled constitutional right to procure an abortion; ${ }^{65}$ and, most recently, the right of religious schools to exemptions from antidiscrimination law for the hiring of their "ministerial" teachers ${ }^{66}$ and the right of religious employers to

${ }^{61}$ See Jonathan L. v. Super. Ct., 81 Cal. Rptr. 3d 571 (Cal. Ct. App. 2008); see also Wisconsin v. Yoder, 406 U.S. 205 (1972); Michael E. Hersher, “Home Schooling” in California, 118 Yale L.J. POCKET PART 27 (2008); Robert Reich, Why Homeschooling Should Be Regulated, in HOMESCHOOLING IN FULL VIEW: A READER, 109 (Bruce S. Cooper ed., 2005); Robert Reich, On Regulating Homeschooling: A Reply to Glanzer, 58 EDUC. THEORY 17 (2008); Kimberly A. Yuracko, Off The Grid: Constitutional Constraints on Homeschooling, 96 CALIF. L. REV. 123 (2008).

${ }^{62}$ For a defense of this right, see generally Ronald Dworkin, Thomas Nagel, Robert Nozick, John Rawls, \& Judith Jarvis Thomson, et al., Assisted Suicide: The Philosophers' Brief, N.Y. REV. OF BOOKs, Mar. 27, 1997, at 41.

${ }^{63}$ Nat'l Fed'n of Indep. Bus. v. Sebelius, 132 S.Ct. 2566, 2585-91 (2012); West, Exit Rights, supra note 26.

${ }^{64}$ District of Columbia v. Heller, 554 U.S. 570 (2008).

${ }^{65}$ Roe v. Wade, 410 U.S. 113 (1973).

${ }^{66}$ Hosanna-Tabor Evangelical Lutheran Church \& Sch. v. EEOC, 132 S. Ct. 694 (2012). 
exemptions from the ACA to protect the sensitivities of conscience. ${ }^{67}$ The contrast between the civil right to enter and the constitutional right to exit can be drawn most sharply one-byone. Thus, the civil right to public education, in contrast to the constitutional right to withdraw one's kids from school and homeschool them, reflects values of shared sacrifice and common purpose, both in the ways in which it is funded and in the content of what is conveyed. The civil right is a right to enter a public world of education, while the constitutional right is a right to exit it. The civil right to unpaid leave during a child's infancy is aimed at permitting a parent to enter a familial and parental relation, rather than providing a constitutional right to exit such a relation through abortion. It imposes a responsibility on the community of shareholders, customers, and co-employees for the shared burden of the costs of the care required to nurture newborns or sick family members, rather than an individual right to avoid those costs by aborting the fetus. Again it is a right to enter a world of shared responsibility for parenting, while the constitutional right is a right to exit both the biological relationship with the fetus and with other potential caregivers. The civil rights to physical security implied by VAWA and decent gun control laws create a community of trust and shared interest among community members who have laid down their arms and a state's police force, rather than a distrust of either the competency or desires of the police to provide that protection, reflected in the Second Amendment's right to arms. The civil right is a right to enter that social compact of protection for forbearance, while the constitutional right is a right to exit it. The civil right to health care spreads the burden of sickness and illness over a community through the mechanism of shared risk, rather than on an individual's constitutional right to either self-insure, self-help, or commit suicide. The civil right to health care is a right to enter a civil world of shared risk, cross-subsidizing insurance, and, at the end of life, communal hospice care, while constitutional rights to die and to refuse insurance are rights to exit just those worlds. And of course, the civil rights to nondiscrimination - the rights of belonging, as Zeitlow dubs them-protect rights to enter employment and education institutions, while the "freedom of the church" now being pressed by scholars and to some extent by courts, protects the rights of churches, and the schools and hospitals they sponsor, to exit those laws, through blanket exemptions in the case of churches themselves, and various "ministerial exceptions" and "conscience exemptions" for the schools and hospitals they sponsor. In each of these examples, the civil right, unlike the constitutional one, not only envisions a community constituted by the civil right to enter, but rests on an assumption of trust and common purpose between the individual holder of the civil right and his co-citizens: parents, teachers, neighbors, and taxpayers share the burden of educating children; employers, co-workers, and customers of an enterprise as partners in the financing and support of new parents; a community of insured individuals and medical professionals sharing the burdens and risks of sickness of each member, and between neighborhoods and police empowered to minimize violence in responsible and humane ways. In other work ${ }^{68}$ I have put forward the claim that these constitutional "exit rights" represent the first wave of an emerging new paradigm of constitutional individual rights. Unlike earlier First, Fourteenth, and Fourth Amendment rights valorized during the first two thirds of the last century, this new generation of rights - rights to homeschool, to own and

${ }^{67}$ Hobby Lobby Stores, Inc. v. Sebelius, 723 F.3d 1114 (10th Cir. 2013), petition for cert. granted, 134 S. Ct. 678 (Nov. 26, 2013) (No. 13-354).

${ }^{68}$ West, Tragic Rights, supra note 26; West, Exit Rights, supra note 26. 
use a gun in self defense, to procure an abortion, to die, to refuse health insurance, and to exempt oneself from antidiscrimination law by referencing one's conscience or ministerial role-are rights that facilitate not just the liberty of individuals within the confines of civic life, but a quite extreme form of "exit" from civic life, and from the community and the state that structure it. They guarantee exit from some aspect of the social contract that defines civil society. The constitutional right to own a gun and to use it in self-defense is a right to not participate in - to exit - the traditional liberal social compact, by which we disarmrelinquish our right to self help-in exchange for the sovereign's duty to protect us from private violence. It envisions an erected wall of distance, difference, and lethality, not only between the individual gun owner and the intruder who endangers his life and interrupts his solitude, but also between the individual gun owner and the state and its police force who have failed to protect him, the community from which intruders come, and neighbors who must be kept at bay. It is a right to exit that part of the social contract constituted by the trade of one's right to self-help, in exchange for the civil right to protection from private violence. The constitutional right to die is a right to exit not just life itself and all its biological ties, but also the social compact by which that life is protected against self-abnegation. It protects the most isolated, solitary, non-communitarian act an individual can possibly make, against the paternalistic interventions of community, family, medicine, or state. The abortion right as well, obviously older, but consistent with these newer rights, is a right to exit an unwanted relationship, not only with the fetal life within, but also from the community, family, or state that seeks to protect it. Both killing oneself and aborting fetal life do, after all, like killing an intruder in justified self-defense, sever earthly coils. The right to homeschool one's children with no supervision from a school or school board, recognized by some lower courts as well as by school districts in several cash-strapped states, is similarly a "right to exit" from the civic and shared project of inter-generational public education, with its shared liberal norms of tolerance, pluralism, and feminism all. The homeschooling parent seeks to exit the shared communal project of education as well as, oftentimes, its shared goal: a civic life informed by norms of tolerance, gender and racial equality, and individual, but civic, autonomy. The right to not buy health insurance, heartily insisted upon by Chief Justice Roberts as well as numerous commentators is likewise a "right to exit:" this time, from the shared societal project of pooling health risks through the mandatory purchase of insurance. All of these new-found rights (the oldest of the group being the abortion right) are echoes of the much older Lochner-era contract right, which, within the context of employment, confers an explicit right to "exit," at will, the employment relation.

In all of these cases, the individual's constitutional exit right is, in form, a negative right protecting individual liberty against an intrusive state. But they are not only that. Exit rights protect not just an individual's liberty within a community, but more radically, an individual's willed separation from the community, or from some threatening part of it: a moralistic state, with its intrusive sonograms and impediments to reproductive choice, a totalitarian state with its threatening black helicopters, or an incompetent state, with its ineffectual police force, poor educational pedagogy, a liberal state, with its offending teachers preaching noxious norms of inclusion and respect, or a nanny state with its mandatory insurance policy, and its forced sharing of risk and co-shouldering of costs. In every one of these cases, the constitutional right found by the Supreme Court, or ardently desired by advocates, is not only not a civil "right of belonging," quasi or otherwise. It is the antithesis of one. The constitutional right protects the individual's right to exit the very 
community that the civil right, at least on the Painean conception, protects, nurtures, and seeks to promote. Civil rights and constitutional rights are not mutually constitutive. They are on a collision course.

Let me draw out one further contrast. Part of what is distinctive about exit rightsrights to homeschool, to kill oneself, to abort a pregnancy, to refuse to buy health insurance, to exercise lethal self-help against violence-is their tragic hue. They protect a radical separation of the self from others, or, at best, an extreme alienation from the civic national community: the homeschooled child is homeschooled precisely in order to maintain or erect a strict separation from that community; the health insurance holdout wants nothing to do with an obligation to support co-citizens in a mutual web of obligation toward a mutual goal of a healthier community; the gun owner risks his own death and that of loved ones as the price he willingly pays for his rights of self-defense against hostile outsiders and an ineffectual (or worse) police force; the "free contractor" from the Lochner era deals with unhelpful co-contracting employees or employers through the right to exit at will; the suicidal individual and the woman obtaining an abortion are both dealing in death. And, in each case, the constitutional exit right separates the individual from some feared part of the physical, biological community: from a fetus that may threaten a woman's life or wellbeing, a threatening intruder that endangers a homeowner's life, a public school teacher with liberal norms of forced ideological inclusion and equality, and most poignantly, the suicidal individual from his own pained body. All of this recalls, if nothing else, classical definitions of tragedy: in the last act of Shakespearean or classical tragedy, the characters wind up dead on the stage, with the community or state from which they came, torn asunder. In constitutional tragedies, those dead individuals as well as those who killed them are shrouded in rights.

Painean civil rights, by contrast, are comedic rather than tragic. The last act of a comedy typically culminates in a community ritual, such as a wedding celebration, or the birth of a child, that reaffirms the value of a shared, communal life, both for the individuals involved and for the larger society. Our civil rights are "comedic" in precisely this way. If Title VII of the Civil Rights Act is working properly, then the last scene of the last act of that legal drama is a workplace that is actually integrated, not a society of atomistic individuals who have rights against irrational state classifications. If Title IX is functioning properly, then in the last act, universities and colleges are healthier communities: women are actually playing on sports teams and African Americans are actually participating in classrooms. When the Family Medical Leave Act is working properly, actual workers tend to dependents in their real-life families, creating stronger communities in both homes and workplaces. The parent nurtures the newborn child, or the adult child cares for the parent, and both do so without fear of losing her place in the workforce. When civil rights to education are secured, then the classroom is public, in all senses of the word-publicly-funded, publicly-supported, open to all comers, and serving the public that funds it. It educates for citizenship and fulfilling lives. When labor rights are enjoyed, workplaces are healthier, better paid, and more participatory. With the civil right to marry secured, the couple weds, in a ritual of communal reaffirmation, toward the end of a communally-recognized shared life. With the civil right to gun safety and gun control, the neighborhood is safe, and the individual and her community are supported and healthy. In the last Act of comedy, not just individuals but also the communities in which they live, are on stage, celebrating the civil rights that unite and support them. 
There is, it is important to note, nothing Dionysian or even romantic about any of this. These rituals are made possible by law, and lots of it, not by an inherently sociable nature. All of these rituals - a marriage, the opening of a school, the integration of a workplace, the care of a newborn, the policing of a neighborhood-are not just dependent upon, they are fully constituted by law and legalism. The workplace is a product of contract, property, and labor law; the parent's nurturance of a newborn without fearing loss of employment is a product of an act of Congress; the safe neighborhood is the end result of the social compact that exchanges, at its core, the natural right of self-help with the mutual obligations of a communally funded and manned police force; the healthy individual owes her health to the pooling of risk, itself facilitated by a set of tax and spending acts of Congress; and civil marriage, as commentators on all sides of the debates surrounding its expansion have noted, ${ }^{69}$ is a product of law and legalism, not of faith traditions. There is nothing particularly romantic, and certainly nothing anarchic, about any of these rights. Health care is not something we enjoy by nature's bounty; it is something we enjoy if we have structured our community and its laws in a way conducive to pooled risk. Education is not something that Emile will pick up willy-nilly if we would but leave him to his own devices; it is a highlystructured product of law, bureaucracy, deliberation, compromise, and pedagogy. Safe neighborhoods are not the spontaneous flowering of a natural Homo sapiens community in Walden Pond; they are the deliberate outcome of a self-motivated contract through which we exchange our own natural rights of self-defense for a web of communal protection. Our own health is not something we will enjoy in a state of nature; quite the contrary, our lives in such a state would be both nasty and short, even without the brutishness of others. It is something that is produced through effective law facilitating the production and distribution of effective medicine and medical care. An integrated workforce, and access to fair labor, is not the natural product of a primitive instinct to bargain or unstructured, spontaneous contracts without need of public enforcement. Rather, it is the product of legalistic constraints on those instincts. Civil rights speak to our capabilities, our respect for community, and our recognition of how law is in service to those communal instincts. They speak to law's virtue and law's necessity, not to law's mendacity or irrelevance. They are, in short, rights to law, not rights to be free of it. We would not enjoy the goods they promise or the capabilities they protect-health, education, welfare, safe neighborhoods, decent work, family, and marriage-without law's presence.

\section{Conclusion: Civil Violence, Civil Rights}

In contemporary usage we tend to conflate civil rights, and the idea of civil rights, with the antidiscrimination law that protects those rights. This is a mistake. Antidiscrimination law protects us against unequal enforcement of our civil rights, particularly where that unequal enforcement is due to racial discrimination or classification on the basis of irrational criteria. Our civil rights, though, are not simply the rights we have to that nondiscrimination. Rather, they are rights to participate in our community in all of the ways peculiarly facilitated by law, which we have a right to enjoy free of the discrimination

${ }^{69}$ See e.g. Ralph Wedgwood, The Meaning of Same-Sex Marriage, N.Y. TIMES, May 24, 2012; Sunday Dialogue: Rethinking Marriage, N.Y. TimeS, Oct. 27, 2012. 
that would deprive us of them. By conflating the antidiscrimination norm with the civil rights that norm protects, we have unnecessarily truncated the natural development of our understanding of the contribution our very civil law makes to our very civil society, and to the aspects of the good life that civil law facilitates, and for which law is so architecturally central.

By way of conclusion, look again at the killing of Trayvon Martin, the trial of George Zimmerman for that death, and its aftermath. The failure to find Zimmerman guilty of second-degree murder ${ }^{70}$ may or may not be attributable, in part or whole, to either intentional or unintentional racism on the part of the jury, the judge, the community, the prosecutors, the expert witnesses, the police force, and the defense team. If it was, then there may have been a violation of not only the antidiscrimination norm in the abstract, but also of Martin's civil rights, both as I've defined them here and as traditionally defined, primarily to security and protection. But whether or not that is the case, there is another violation of Martin's civil rights revealed by that tragedy, but which is not fundamentally a function of racismalthough it is certainly exacerbated by it. "Stand your ground" laws, ${ }^{71}$ as well as newly broadened self-defense laws that expand the scope of permissible violence in altercations, ${ }^{72}$ basically expand the scope of justified lethal force to include all scenarios in which a combatant is in fear of his life, regardless of who or what triggered the fight that put him there. You can, that is, stalk someone as long as your "stalking” is itself legal, pick a fight with him, find yourself losing that fight, consequently fear for your own life, and then fire a gun with the intent and hope to kill, all in justified self-defense. That's what Zimmerman did. Martin's mistake was to fight his stalker, and effectively.

${ }^{70}$ Lizette Alvarez \& Cara Buckley, Zimmerman Is Acquitted in Trayvon Martin Killing, N.Y. TiMES, July 13, 2013.

${ }^{71}$ Over half of the states now have enacted "stand your ground" laws, at the instigation of the NRA, in most states. See, e.g., ALA. CODE $§ 13 A-3-23(b)$ (2013) (“A person who is justified under subsection (a) in using physical force, including deadly physical force, and who is not engaged in an unlawful activity and is in any place where he or she has the right to be has no duty to retreat and has the right to stand his or her ground.”); FLA. STAT. § 776.013(3) (2013) ("A person who is not engaged in an unlawful activity and who is attacked in any other place where he or she has a right to be has no duty to retreat and has the right to stand his or her ground and meet force with force, including deadly force if he or she reasonably believes it is necessary to do so to prevent death or great bodily harm to himself or herself or another or to prevent the commission of a forcible felony.”). Eric Holder has recently joined a chorus of criticisms of stand your ground laws for increasing the number of killings in states that have enacted them. See Attorney General Eric Holder, Remarks at the 2013 NAACP Annual Convention (Jul. 16, 2013) (transcript available at http://articles.washingtonpost.com/201307-16/politics/40608813_1_trayvon-martin-rights-leaders-justice-department).

72 The judge in the Zimmerman case instructed the jury that Zimmerman was entitled to stand his ground and use lethal force, if he reasonably believed his life was in danger. Prior to Florida's passage of stand your ground legislation, the instruction would have been that he was not so entitled if he had a reasonable way to avoid the altercation. See generally Outcry Unlikely to Spur Change in Stand-Your-Ground Law, CBS NEWS, Jul. 22, 2013, http://www.cbsnews.com/news/outcry-unlikely-to-spur-change-in-stand-your-ground-law/; FLA. STAT. § 776.013(3) (2013). 
Zimmerman's justified lethal violence, because it was lawful "self-defense," was not criminal. That which is not criminal is legal. So, when we expand self-defense law with stand your ground laws, and simultaneously protect rights to carry weapons, we have in effect changed the terms of our civil, or social compact: some measure of public, "civic violence" is now fully permitted, that was fully criminal a very short time ago. When we embrace broad defenses that shrink the sphere of criminal lethal violence, we not only expand the scope of permissible individual self-help in altercations, we also shrink the sphere of the pacific civility that is expected of us in our public as well as private spaces. If a combatant is permitted to carry a gun, start a fight, and then "stand his ground," regardless of what he did to trigger the assault, virtually every fistfight, regardless of how it began, becomes, potentially, a justified homicide. The sphere of peaceful co-existence - of community - is gravely reduced.

It seems to me that on Paine's understanding, this entire body of newly made law, with state statutory and U.S. constitutional underpinnings both, far more clearly than the jury verdict acquitting his killer, is a massive violation of Trayvon Martin's civil rights. By virtue of its enactment, Trayvon's civil right to the enjoyment of his physical security, and his equally civil right to the state's protection of his physical security, is what was not protected that night, on his walk back from the store to his father's apartment. The core civil right, Paine urged, is the right to the state's protection of one's physical security. That protection, to which we have a right, is and must be provided by the state; it is the paradigmatic right that we cannot perfect on our own. The authors of the $1871 \mathrm{Ku}$ Klux Klan $\mathrm{Act}^{73}$ realized this. The authors of the Equal Protection Clause of the Fourteenth Amendment recognized this. The authors of the late twentieth century's Violence Against Women Act recognized this. The authors of our various Criminal Codes recognize this. Yet, somehow, we've lost track of the civil rights underpinning of our right to be protected, by the state, against private violence. Instead, we shrink the scope of the right to be protected, while constitutionalizing various rights to kill each other. I am not urging a massive enlargement of our overly punitive criminal justice system. But it hardly follows from the sad fact that our criminal justice system is unjust, that what we should do is return the streets to the armed. The result of the abandonment of the civil right to protection against violence, and the civil duty of the state to provide it, whether through the defunding of police forces or the expanding of "self defense” principles, is and will continue to be carnage, in homes, schools, and on public streets.

That carnage, no less than discriminatory law enforcement, is a central civil rights issue of our age. It should not need to rear its head only in the aftermath of spectacularly tragic public killings of innocents. There is now no question but that this breach of our civil rights - the failure of the state to protect all of us against private violence-impacts blacks more than whites, and black youth far more than white youth. It is young black men and boys, more than white men, who are targeted not only by ordinary crime but also by vigilante neighborhood watch groups staffed by white men carrying guns, and whose death-dealing acts of killing can then be tallied as justifiable homicide. The "civil right," then, of which young black men are deprived, is not only the right to be free of discriminatory policing, discriminatory profiling, and discriminatory sentencing policies, it is also the civil right to live out their lives without fear of intimate and neighborly_and, as it turns out, fully legal-

7342 U.S.C. $\S \S 1983,1985,1986$. 
violence, every time they walk from their homes to their neighborhood stores. Both they and all the rest of us are deprived of that right, by virtue of neutral-sounding expansions of our self-defense laws, stand your ground laws, open carry laws, and constitutionally-grounded gun rights, all of which, collectively, have an horrifically adverse impact on minority communities. But the existence of the civil right these laws offend does not depend on such a showing. The thoroughly positive right to thoroughly positive, state-provided protection against thoroughly private violence is a — maybe the-quintessential civil right: it is a right that can only be realized through the enactment of positive law, and its fair enforcement. It is the civil right to the protection of the state against the private violence occasioned upon him by George Zimmerman, as accomplished here through the state of Florida's quite intentional shrinkage of their criminal law of homicide, which was denied Trayvon Martin.

A civil right, again, is a civil right to law-in this case, to laws criminalizing private violence. That civil right cannot be realized through negative rights to be free of law, nor can it be realized by rights to be free of state or private discrimination. It cannot even be seen, in fact, as a civil right, so long as we remain besotted by our negative constitutional rights to be free of the state, leavened only by our insistence that the state not irrationally discriminate between us. Neither of the two dominant understandings of rights that circulate in our contemporary legal culture-our understanding of our beloved negative constitutional rights that shrink the role of the state in our lives, or our limited understanding of our equallycherished civil rights to nondiscrimination — no matter how seriously we regard them, will be much help on this one. All the constitutional rights and antidiscrimination rights in the world would not have helped Trayvon Martin against George Zimmerman's fully legal lethal force. For that, we need to regenerate interest in and commitment to the rights to civil society, including Trayvon's vital civil rights to physical security and mobility, envisioned by early and forgotten architects of our classical civil rights tradition. 